\title{
Inflation targeting and economic performance over the crisis: evidence from emerging market economies
}

\author{
Thuy Hang Duong \\ Australian National University, Canberra, Australia
}

\begin{abstract}
Purpose - Inflation targeting has increasingly become a popular monetary framework since its first introduction in New Zealand at the beginning of 1990 . However, the causality effects of this policy on economic performance, particularly in periods of economic turmoil remain controversial. Thus, this paper re-examines the treatment effect of inflation targeting on two important macro indicators which are inflation rate and output growth with the focus on emerging market economies. The global financial crisis, which is known as the great recession since the last decade, is investigated as an exogenous shock to test for the effectiveness of this popular regime.

Design/methodology/approach - The difference-in-difference approach in the fixed-model is employed for this investigation using a balanced panel data of 54 countries with 15 inflation-targeting countries for the period 2002 to 2010 .

Findings - The examination finds that there is no significant difference in terms of the inflation rate and gross domestic product growth over the whole research period between the treatment and control groups. However, the outcome suggests that emerging economies can control the increase in inflation rate when the economy has to cope with the exogenous uncertainties.
\end{abstract}

Research limitations/implications - This finding indicates important policy implications for central banks in many countries.

Originality/value - Inflation targeting can help emerging countries to reduce an increase in inflation rate in the crisis period without many trade-offs in the growth of output.

Keywords Inflation targeting, Global financial crisis, Emerging market countries, Difference-in-difference approach, Fixed model

Paper type Research paper

\section{Introduction}

Many may continue to remember the global financial crisis which originated from the collapse of the US housing market in 2007, ruining several financial markets globally. This crisis is known as the Great Recession. Estimates from the International Monetary Fund (IMF, 2010) show that real gross domestic product (GDP) growth in emerging and developing economies fell dramatically from $8.3 \%$ in 2007 to $6.1 \%$ in 2008 , then to $2.4 \%$ in 2009 . Inflation doubled in many countries during this period. While the consequences are on a global level, the magnitude of effects differed by country (Claessens et al., 2010).

As such shocks are risks in the context of the global economic integration, choosing a sound monetary framework to mitigate or even eliminate the consequences of economic

(C) Thuy Hang Duong. Published in Asian Journal of Economics and Banking. Published by Emerald Publishing Limited. This article is published under the Creative Commons Attribution (CC BY 4.0) licence. Anyone may reproduce, distribute, translate and create derivative works of this article (for both commercial and non-commercial purposes), subject to full attribution to the original publication and authors. The full terms of this licence may be seen at http://creativecommons.org/licences/by/4.0/legalcode.

The author is grateful to Professor Blane D. Lewis and Mr. Phan Le for the guides and comments that helped significantly improve the quality of this study. Any errors and shortcomings, if any, remain the author's responsibility.

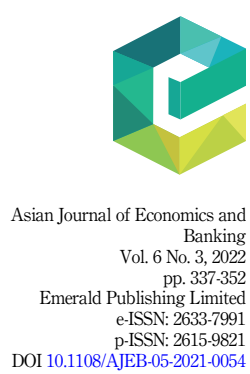


AJEB 6,3

disturbance is an important mandate for any central bank. In 1990, inflation targeting was first introduced by the Reserve Bank of New Zealand; gradually, it has been adopted by an increasing number of central banks as a strategy for monetary policy implementation. Under the inflation-targeting framework, the central bank officially announces a unique numerical target in the level or a range for annual inflation. Thus, this regime is expected to act as a guide for inflation expectations, assure a low and stable inflation rate and improve the central bank's credibility. However, to date, the effectiveness of this monetary framework remains controversial among policymakers and macroeconomists (Ball and Sheridan, 2004; Vega and Wikelried, 2005; Stiglitz, 2008).

Numerous studies have been conducted to address whether inflation targeting matters (Ball and Sheridan, 2004; Gonçalves et al., 2006; Batini and Laxton, 2007; Lin and Ye, 2007, 2009; Samarina et al., 2014); nevertheless, significantly less analysis has been undertaken on evaluating this regime in the existing global economic downturn. On the empirical front, the work of Neumann and Von Hagen (2002) is one of few papers considering the impacts of inflation targeting implementation in periods of economic crisis. They compare the performance of inflation targeting and non-inflation targeting central banks under two exogenous shocks; namely, the oil price hikes of 1978 and 1998. Using the difference-indifference approach with a sample of nine countries (six of which have adopted inflation targeting), they provide optimistic evidence about the performance of this policy in terms of lower levels of inflation, less volatile inflation and lower interest rates. Similarly, Miskin and Schimidt-Hebbel (2007) examine the macroeconomic and monetary policy performance of the inflation targeting policy before and after the oil price shock of 1997-1998 but use a more diverse sample of 34 industrial and emerging countries. The results from their panel vector autoregressive (panel VAR) models show that this monetary framework helps the targeters reduce the domestic inflation response to an oil price shock relative to periods before the adoption of inflation targeting and to the non-targeting countries. However, in terms of macroeconomic performance, Miskin and Schimidt-Hebbel (2007) find that emerging countries experienced major reductions in output as a trade-off for stable inflation.

Some recent studies focus on the global financial crisis of 2007-2008 to evaluate the treatment effects of inflation targeting. To the best of the author's knowledge, the first to publish on this theme is de Carvalho Filho (2010), who used the fixed effects model for a sample of 84 advanced and emerging countries from January 2006 to August 2009 to compare inflation "targeters" and "non-targeters" in terms of the monetary policy responses and economic activity outcomes. His findings highlight the role of inflation targeting in smoothing this shock more effectively than the outcomes observed in their non-inflation targeting peers. Targeting countries enjoyed lower nominal policy rates, lower sovereign default risk and higher GDP growth rates in comparison to their counterparts. This conclusion regarding the positive impact of the inflation targeting policy on GDP growth is not supported by Armand (2012). Considering the same control group and same break-date of the financial crisis of 2007 used by de Carvalho Filho (2010), using the difference-in-difference models, Armand (2012) reveals an insignificant impact of this framework on GDP growth and inflation rate for both groups of countries.

Considered together, while these papers provide good evidence for treatment effects of inflation targeting policy on inflation control in the periods of economic disturbance, conclusions for the role of this policy in promoting GDP growth have limited consensus. Moreover, there are certain drawbacks of the empirical procedures in previous studies making their evaluation regarding the effectiveness of inflation targeting ambiguous. First, on the matter of the data, Blinder et al. (2008) suggest that the selection of the control group plays an important role in this line of research. Unfortunately, not all previous studies consider this issue carefully. Neumann and Von Hagen (2002) use a very small sample of three countries in the control group. Thus, it is unreasonable to generalize the treatment effect of 
the inflation targeting regime. In Miskin and Schimidt-Hebbel (2007) and de Carvalho Filho (2010), the number of observations is larger, but no particular explanation of selected countries is provided. Second, the possibility of endogeneity is ignored in the difference-indifference models of Neumann and Von Hagen (2002). The adoption of inflation targeting is probably an endogenous choice considering different periods and unobserved macroeconomic situations. Hence, research that does not control for these initial conditions or for the time and country fixed effects tends to produce biased results. Following Ball and Sheridan's approach (2004), Armand (2012) controls the initial output when modeling the treatment effect of inflation targeting in an effort to deal with the endogenous issues. However, the satisfaction of the underlying assumption of a parallel trend in Armand's difference-in-difference approach (2012) appears to be ignored which could be against his conclusions considering a violated assumption.

Considering the shortcomings, this paper thus aims to re-evaluate the effectiveness of this popular monetary framework on the economy over the periods covering the global financial crisis. The important research questions whether a country that sets the inflation targeting as its primary monetary framework (IT countries for short) can do better in terms of reducing the increase in inflation rate and accelerating the output growth during the crisis period in comparison to the countries that do not apply the inflation targeting framework (non-IT countries for short) are addressed in this paper. This article contributes to the existing literature by providing a comprehensive analysis of inflation targeting impacts on the economy and dealing with the technical issues in previous studies. Specifically, panel data of 54 emerging countries (15 IT countries included) is exploited to simultaneously examine inflation and output outcomes from inflation targeting adoption. Instead of averaging the time-series observations, the author controls for time and country-specific dimensions to improve the inference on the causal effect of this framework. It is worth noting that both de Carvalho Filho (2010) and Armand (2012) evaluate the treatment effect of inflation targeting for periods before and during the global financial crisis in 2008-2009. Nevertheless, as the impact of this recession varied significantly across countries, it is not easy to distinguish if any estimated treatment impact is merely a function of treatment or includes the crisis. In this article, the author undertakes analyzes for the period 2002 to 2010 covering either pre- or post-crisis to avoid these confounding effects.

In contrast to some previous studies, this paper solely focuses on emerging economies as their similar characteristics could lead to a heterogeneous efficiency of inflation targeting regimes while coping with macroeconomics disturbances. Moreover, while many emerging markets experienced high volatility of the inflation and output before adopting inflation targeting, it is a fact that most advanced countries began this regime with relatively low and stable inflation (Schaechter et al., 2000). Hence, the inflation targeting adoption may not deliver important gains for the economy when considering advanced countries as observations. Furthermore, the main argument in favor of the inflation-targeting framework is that an improvement in credibility can be gained by central banks when they target a specific level or range of inflation. As central banks in emerging countries are likely to have significantly lower initial credibility than advanced peers (Lin and Ye, 2009), it is reasonable to expect that the adoption of inflation targeting regime can substantially improve the credibility of such central banks, which leads to better policy effectiveness in developing countries.

The difference-in-difference fixed-effect model is employed to estimate the treatment effect of inflation targeting policy over the crisis period on two important indicators of the economy, namely inflation rate and output growth. For emerging economies, the study offers some evidence to suggest that inflation targeting is an effective policy that helps IT countries to avoid high inflation during economic uncertainties and maintain a similar performance in terms of output growth when compared to non-IT countries. 
AJEB 6,3

\section{0}

The rest of the article proceeds as follows. In Section 2, the general background of the inflation-targeting framework is provided. Sections 3 and 4 discuss data and methodological issues, respectively. The empirical results for the treatment effects of inflation targeting regime on economic performance are reported in Section 5. Sections 6 and 7 provide tests for the heterogeneity and robustness of estimates, respectively. Section 8 summarizes the main findings of the study and concludes.

\section{Inflation targeting}

\subsection{What is inflation targeting?}

The popularity of inflation targeting as an operational framework for monetary policy has been increasing since its introduction three decades ago. While this framework was restricted to a selected number of industrial countries for a certain period, in recent years, increasingly more emerging markets have been joining them in adopting this monetary policy regime. According to the International Monetary Fund's classification (IMF, 2019), the number of IT countries significantly increased to 41 in 2019, and three-quarters of them were emerging countries (Appendix Table A2). Although the inflation-targeting approach has been adopted in various ways, two main characteristics distinguish this nominal anchor from other monetary policy strategies as followed:

First, under an inflation-targeting framework, the central bank publicly announces a numerical level or range for annual inflation (Gemayel et al., 2011; Bernanke and Miskin, 1997). As targeting inflation directly requires the monetary authorities to forecast the likely path of prices, it is sometimes referred to as "inflation forecast targeting" (Svensson, 1997). A variety of indicators needs to be closely monitored while considering this forward-looking assessment of inflation.

Second, in most cases, the primary focus of inflation considerably reduces the role of formal intermediate targets, such as exchange rate stability, output growth or unemployment rate (Bernanke and Miskin, 1997; Batini and Laxton, 2007). Initial announcements of inflation indicators gradually transit from the current level of inflation to the desired inflation level, then to a steady-state level of price. To the extent that controlling inflation is inconsistent with intermediate goals, where the nominal exchange rate is unlikely to remain stable if the central bank reduces a high level of inflation by adjusting the policy interest rate or selling foreign currency from the national foreign-exchange reserve into the market. Thus, a clear mandate for the monetary authorities under the inflation targeting framework is attaining price stability rather than pursuing a multiplicity of monetary objectives.

\subsection{Why can inflation targeting be expected to cope better than other regimes over periods of economic and financial downturns?}

The existing literature offers some explanations of why inflation targeting can be a sound policy that can help countries mitigate risks from exogenous shocks. First, the inflationtargeting framework plays an important role not only in reducing high rates and volatility of inflation but also in preventing those targeting from persistent deflation which is a significant concern for monetary authorities in the post-crisis (de Carvalho Filho, 2010; Ball and Sheridan, 2004; Vega and Wikelried, 2005; Lin and Ye, 2009). Second, the increasing credibility of policymakers in IT countries helps central banks face economic shocks with a significantly less contractionary monetary policy (Lin and Ye, 2009; Neumann and Von Hagen, 2002). Third, the inflation targeting regime is generally accompanied by a flexible exchange rate regime (de Carvalho Filho, 2010). The flexibility of the exchange rate is an essential factor that absorbs external shocks (Bjørnland, 2004; Edwards et al., 2005). Besides, in terms of fiscal policy performance, Lucotte (2012) and Tapsoba (2010) find that the 
treatment effects of inflation targeting on government revenues are positive and significant. Lucotte (2012) explains that this target encourages governments to strengthen the collection of domestic tax revenue as the monetary policy becomes tighter. An improved fiscal discipline acts as a beneficial condition for economic recovery in the post-crisis periods.

\section{Data}

For each regression, this paper uses balanced panel data of annual series for the period 2002 to 2010, covering years before and after the global financial crisis. The sample countries comprise of 54 emerging countries, including 15 countries that adopted inflation targeting by the end of 2006 (Table 1). Most of the data are collected from the World Bank and International Monetary Fund (IMF)'s International Financial Statistics.

The data set is divided into three sub-periods to evaluate the treatment effects of inflation targeting policy in smoothing the economic shocks. As the global financial crisis originated in mid-2007 following the collapse of the US housing market, the pre-crisis period consists of the 5 years preceding this crisis, from 2002 to 2006 . As pointed in Armand (2012), the consequences of this great downturn were notable until 2009. Thus, this paper examines the crisis period covering three consecutive years from 2007 to 2009. The year 2010 is also added to the baseline model as the post-crisis period to control the confounding effects of crisis consequences.

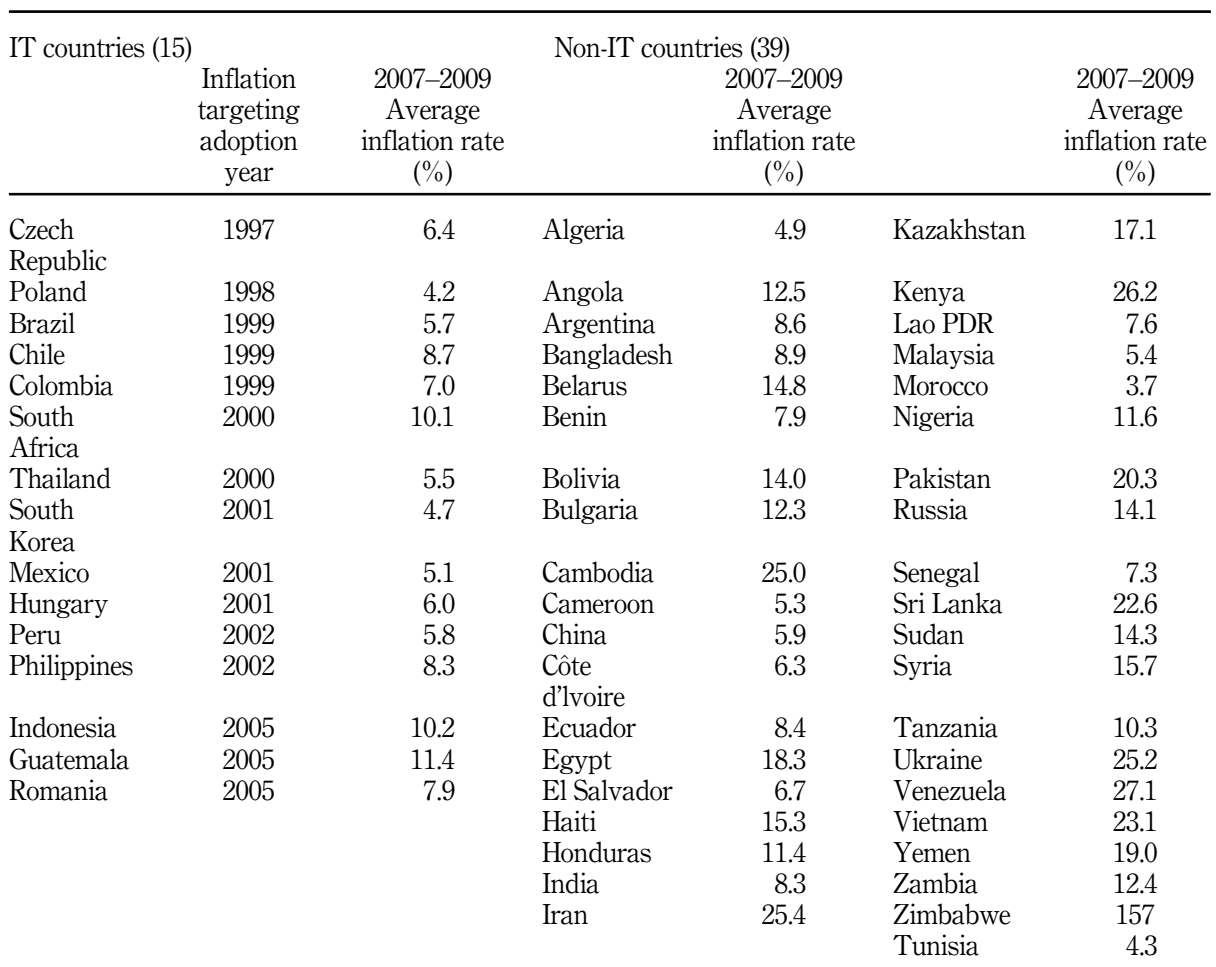

Note(s): Country selection is based on Lin and Ye (2009)'s approach Source(s): IMF (2019), The World Bank Data, Central banks' data
Inflation
targeting and
economic
performance

Source(s): InF (2019), The World Bank Data, Central banks' data 


\section{AJEB \\ 6,3}

342

Figure 1.

Average inflation rate in IT countries

\section{Figure 2 .}

Average inflation rate from 2002 to 2010 in IT and non-IT countries

\subsection{Dependent variables}

The outcome variables considered in this study are the annual inflation rate and annual output growth which represent the economic performance in each country. In this paper, the annual inflation rate is defined as the percentage of changes in the annual Consumer Price Index (CPI), while output growth is measured by the percentage of changes in the annual real GDP.

Figures 1 and 2 represent a comparison of the average inflation rates between pre- and post-adoption of inflation targeting in IT countries from 1985 to 2002 and that between IT countries and non-IT countries during the study period 2002 to 2010, respectively. Similar comparisons of the average output growth are shown in Figures 3 and 4. In Figures 1 and 3, year $T$ is the first year when the inflation targeting policy in each IT country started, and (. ., $T-2, T-1, T+1, T+2, \ldots)$ are one or two years before and after the year $T$ (i.e. if an IT country starts the inflation targeting policy in 2000, then $T=2000, T+1=2001$, $T-1=1999$ ). The adoption years are when countries officially set inflation targeting as the nominal anchor of monetary policy based on IMF classification. The inflation rate and output
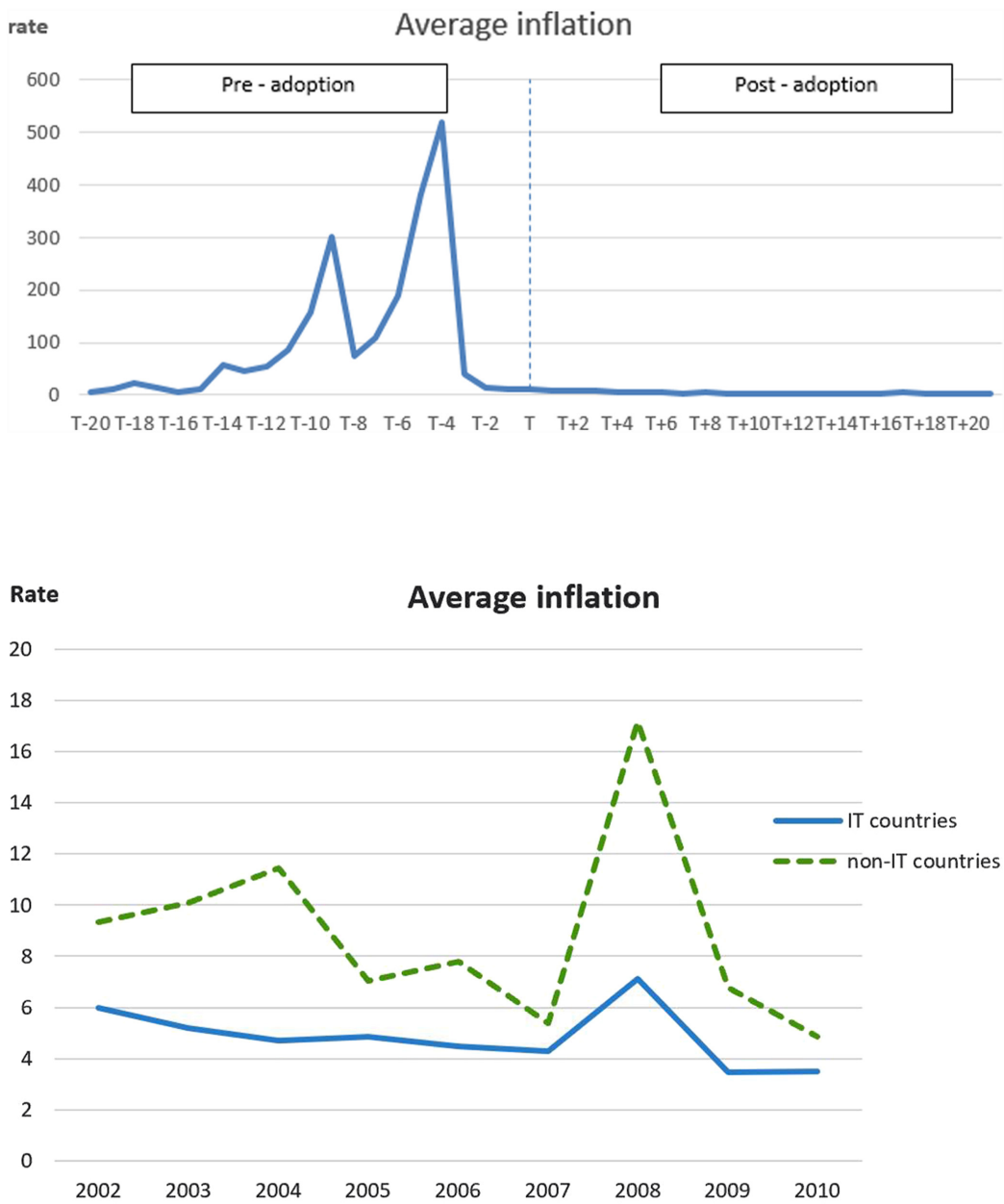


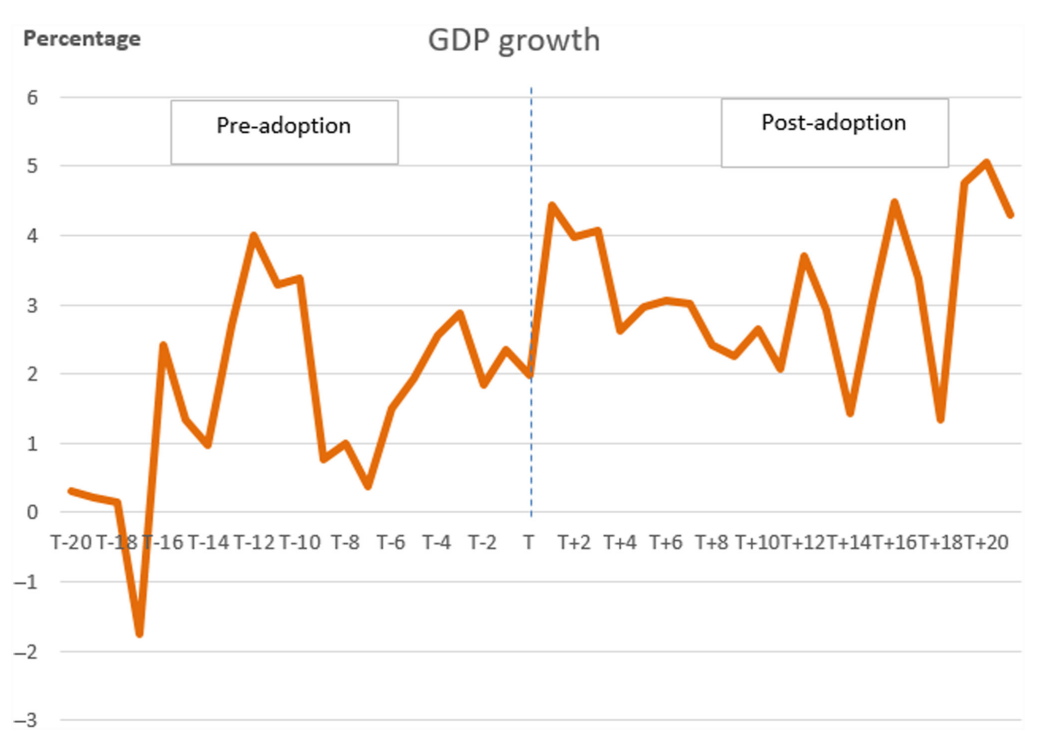

Percentage

Average GDP growth

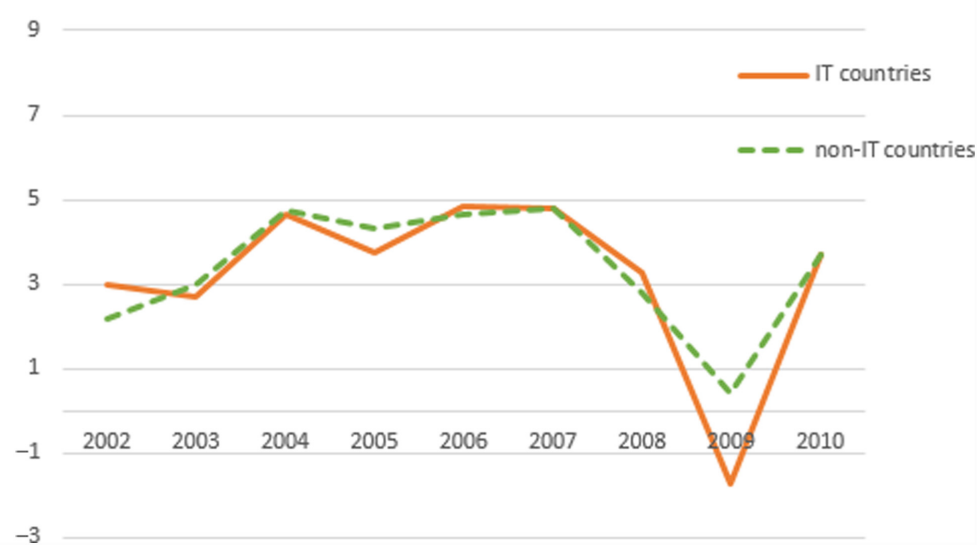

\section{Inflation targeting and economic performance \\ 343}

Figure 3. Average GDP growth in IT countries
Figure 4. Average GDP growth from 2002 to 2010 in IT and non-IT countries

growth in these two figures are the mean values of the inflation rate and GDP growth in countries that have the same year $T$. In Figures 2 and 4 , the inflation rate and output growth are the mean values of the CPI growth and the GDP growth in the treatment group (IT countries) and the control group (non-IT countries) over different periods.

The preliminary results emerging from these figures suggest some noticeable points. First, IT countries experienced periods of high and volatile inflation before implementing the inflation targeting policy, but this rate reduced remarkably and was controlled at low and stable rates since the monetary framework came into effect. Meanwhile, the differences in the average GDP growth in pre- and post- IT adoption in IT countries were not apparent. 
AJEB

6,3

\section{4}

Second, on average, IT countries had significantly lower inflation rates than non-IT countries during the 11-year study period, particularly in the crisis period. The average inflation in treatment countries was only approximately $7 \%$ in 2008 , while that in the control group was $17 \%$ in that year. Generally, there was no significant difference in the GDP growth between these two groups of countries in Figure 4 (except for 2009). These plots seem to indicate that IT countries tend to control inflation rates better than non-IT countries in periods of economic turmoil, while the tradeoffs of GDP growth are not too severe.

\subsection{Control variables and sample countries}

The control variables used in the analysis include variables that could explain the probability that an emerging country chooses specific inflation as a monetary target: the fixed exchange rate dummy variable, the growth of money supply aggregate (M2), trade openness and government debt. All these, except for the exchange rate variable, are described in the percentage of output (GDP). The summary statistic of these control variables and dependent variables is represented in Appendix Table A1.

The treatment group includes 15 emerging market countries that adopted inflation targeting by the end of 2006. As explained in the previous sub-section, the policy adoption years are based on IMF classification. These years are mentioned as "conservative starting years" in Rose (2007) and Lin and Ye (2009). Considering the control group, non-IT countries, this paper follows the selection criterion used in Lin and Ye (2009) to form two groups of countries that can be compared. In specific, the control group includes only non-targeting developing countries that simultaneously satisfy conditions of a real GDP per capita at least as large as the poorest targeting country, and that of population size at least as large as that of the smallest targeting country. According to these criteria, the control group for this subsample consists of 39 countries. Table 1 lists a total of 54 targeting countries and nontargeting developing countries, and the years in which those targeting officially adopted the inflation targeting regime.

In comparison to the sample countries in Lin and Ye (2009), this paper includes three IT countries in the treatment group, namely Indonesia, Guatemala and Romania, as these countries adopted inflation targeting since 2005 and satisfied the criteria mentioned. Israel is removed from the sample as it was promoted from an advanced emerging market to a developed country on 19 September 2008 according to the classification of FTSE Russell (FTSE, 2020). Thus, Israel has exceeded this paper's content in evaluating the treatment effects of inflation targeting among emerging countries. Another noteworthy point is that Poland became an advanced country in 2018. However, the year 2018 is not examined in this study; thus, Poland is suitable to be treated in the treatment group.

\section{Methodology}

The main objective of this study is to test the (null) hypothesis that the inflation targeting framework improves the economic performance in terms of the inflation rate and output growth in the IT countries during periods of economic uncertainty when the global financial crisis is taken into account. The difference-in-difference (DID for short) approach is used to provide the evaluation of inflation targeting impacts on these dependent variables. The DID model can compare treatment and control groups in terms of outcome changes over time. Thus, it is suitable to be employed in this case. Moreover, in comparison to some other quasiexperimental methods, the DID estimator is recognized to avoid selection bias by allowing for unobserved heterogeneity (Khandker et al., 2010). The DID assumes this unobserved heterogeneity is time-invariant. As such, the bias dies out by differencing. As the adoption of inflation targeting may be an endogenous choice depending on the economic situation over different periods (Ball and Sheridan, 2004), the DID approach is estimated in the fixed-effect model to remove unobserved time-invariant confounders. 
The DID specification in the panel fixed-effects is estimated by Equation (1) as follows:

$$
Y_{i t}=\alpha_{1}+\alpha_{2} T_{i t}+\alpha_{3} I_{i t}+\alpha_{4} Z_{i t}^{\prime}+\theta_{t}+w_{i}+\varepsilon_{i t}
$$

In Equation (1), subscripts $i$ and $t$ represent individual countries and year, respectively; $Y$ is the dependent variables which represent inflation rate and output growth; $T$ is a dummy variable denoting inflation targeting implementation in the crisis period, which takes on the value of one for years from 2007 to 2009 in IT countries, else zero; $I$ is a dummy variable denoting the adoption of inflation targeting for all the study period, which equals one for all years after the adoption, else zero; $Z$ ' includes covariate variables, detailed below; $\theta$ are time fixed effects; $w$ are country fixed effects, which control for time-invariant impacts on economic performance across countries; $\varepsilon$ is the error term; and $\alpha_{1}, \alpha_{2}, \alpha_{3}$ and $\alpha_{4}$ are the parameters to be estimated. The examination focuses on $\alpha_{2}$ and $\alpha_{3}$ which represent the estimated treatment effect of the inflation targeting policy during the crisis period and since the adoption in IT countries, respectively.

Covariate variables include the dummy variable for the fixed exchange rate regime, the growth of money supply aggregate (M2), trade openness and government debt.

The key assumption of the DID approach is parallel-trend satisfaction, which means that outcomes display equal trends in the absence of treatment. In other words, unobserved characteristics affecting treatment participation do not vary over time with treatment status (Khandker et al., 2010). A violation of the parallel trend assumption may lead to a biased estimation of the causal effect. Thus, in this paper, the validity of this critical assumption is tested by applying three different tests based on Wing et al.'s approach (2018):

(1) Granger-type causality test: The first and second leads of the treatment dummy variable are added to Equation (1) to examine the possibility that future treatment exposures are anticipated by current outcomes. Under the key assumption, future policy changes are expected to not be associated with current outcomes. Thus, the estimated coefficients of these leads should be statistically insignificant.

(2) Group-specific linear time trend: Each group effect interacts with the linear time index, then this interaction term is added to Equation (1). The common trend suggests that these group-specific linear time trends should be jointly insignificant. An $F$-test of the compound null is used to check for insignificance.

(3) Covariate balance test: The DID validity assumes that differences between the two groups are stable over time; thus, changes in the distribution of covariates do not affect treatment exposure. In this approach, the DID validity is examined by estimating covariate balance regressions. In Equation (1), the outcome variable is replaced with covariates. Then, each covariate is regressed against the treatment variable and group, and year fixed effects. The estimated coefficients attached to the treatment variable should be insignificant in all or almost all regressions for a valid assumption.

\section{Empirical results and interpretations}

Equation (1) is estimated for both the inflation rate and output growth from 2002 to 2010 . As mentioned in the previous section, estimation for the DID model is applied in the fixed effects approach. Standard errors are clustered at the country level to eliminate the serial correlation over time within groups. All regressions include constant, covariate variables as specified in the text, fixed time effects and fixed country effects. The outcomes from the DID fixed effect approach are reported in Table 2.
Inflation
targeting and
economic
performance

345 
$\underset{6,3}{\mathrm{AJEB}}$

\begin{tabular}{|c|c|c|c|c|}
\hline \multirow[b]{3}{*}{ Independent variables } & \multicolumn{4}{|c|}{ Dependent variables } \\
\hline & \multicolumn{2}{|c|}{ Inflation rate } & \multicolumn{2}{|c|}{ Output growth } \\
\hline & Coefficient & Robust SE & Coefficient & Robust SE \\
\hline IT implementation in the crisis period & $-2.220^{* *}$ & 0.980 & -0.562 & 0.705 \\
\hline IT implementation & -3.114 & 3.818 & -0.686 & 0.979 \\
\hline Fixed exchange rate regime & -3.404 & 3.381 & 0.572 & 0.668 \\
\hline $\mathrm{M} 2$ growth (\% GDP) & $-0.192^{* * *}$ & 0.070 & $-0.130 * * *$ & 0.032 \\
\hline Trade openness ( $\%$ GDP) & $0.110^{* *}$ & 0.053 & $0.044^{* *}$ & 0.020 \\
\hline Public debt (\% GDP) & $0.062^{* *}$ & 0.024 & -0.007 & 0.012 \\
\hline Constant & $8.848^{*}$ & 5.160 & $5.981 * * *$ & 1.859 \\
\hline Number of groups & \multicolumn{2}{|c|}{54} & \multicolumn{2}{|l|}{ (1) } \\
\hline Number of observations & \multicolumn{2}{|c|}{467} & \multicolumn{2}{|c|}{472} \\
\hline$R^{2}$ (within) & \multicolumn{2}{|c|}{0.132} & \multicolumn{2}{|c|}{0.305} \\
\hline
\end{tabular}

Table 2.
The impact of inflation targeting on the inflation rate and GDP growth from 2002 to 2010

Note(s): All regressions include constant, covariate variables as specified in the text, fixed time effects, and fixed country effects. Robust SE is standard error clustered at the country level. ***, ** and * indicate statistical significance at the 1,5 and $10 \%$ level, respectively

Source(s): Author's calculation

As per Table 2, the estimated coefficient associated with inflation targeting implementation (IT implementation) is statistically insignificant as the inflation rate is the dependent variable. This output suggests that the inflation targeting framework has no apparent impact on the inflation rate in IT countries after the adoption, all else remaining unchanged. However, during the crisis period, the impact of inflation targeting on the inflation rate is statistically significant at $5 \%$ level. The specific results show that by applying inflation as the priority target, emerging economies can reduce the annual inflation rate by $2.2 \%$ relative to the nonIT group when the economy faces uncertain events.

The estimated treatment effect of the inflation targeting policy on output growth is represented in the two last columns in Table 2. As the GDP growth is the dependent variable, the estimates for the inflation targeting implementation in emerging economies are statistically insignificant in either the crisis period or the stable period, all else remaining the same. Thus, in comparison to countries that pursue other primary monetary frameworks, rates of GDP growth in IT countries do not increase or decrease significantly via the inflation targeting policy over different periods.

These outcomes indicate that the inflation targeting policy helps emerging economies lower their inflation rate without placing a heavy burden on the output growth during an economic disturbance. This finding is consistent with the preliminary analysis in Section 3 which plots the remarkably lower rate of inflation in IT countries relative to the control group during the crisis period. The significant impacts of inflation targeting regime on lowering inflation rate covering the periods of economic shocks also fit with the extant literature, such as Neumann and Von Hagen (2002), Miskin and Schimidt-Hebbel (2007) and de Carvalho Filho (2010). In terms of output growth, the treatment effects of this monetary framework are insignificant which are supported by the conclusions in Armand (2012). However, Miskin and Schimidt-Hebbel (2007) and de Carvalho Filho (2010) have contrast results to this paper in terms of the impacts on GDP growth. As mentioned in Section 1 of this paper, this difference could stem from the limitations of prior works in choosing improper control groups as well as dealing with selection bias issues.

The outcomes of the parallel trend tests based on Wing et al.'s (2018) approach are represented in Appendix Table A3. Only the results of the main interests are shown in the table. As the table shows, two out of three tests support DID validity. The tests for the Granger-type causality procedure are implemented on estimates regarding the impact of 
inflation targeting policy on both dependent variables. Neither the first nor the second lead of the dummy variable of inflation targeting implementation have significant impacts on the inflation rate and output growth. The initial outcomes are not affected by anticipated effects; thus, the key assumption in the DID model appears to be valid in this approach.

This assumption is also satisfied by the covariate balance test. The specific results show that there is no estimated coefficient of the dummy variable for IT implementation which is statistically significant at 1 and $5 \%$ levels. This outcome indicates that the estimated treatment effect is not associated with changes in the distribution of covariates; hence, the estimates are stable over time. Only the test for group-specific linear time trend suggests that the parallel trend assumption should be problematic as the null hypothesis for the joint test of insignificant time-trend interaction terms is rejected. However, the assumption violation in this group-specific linear time trend test means that the core results should be considered more credible (Wing et al., 2018) rather than concluding them to be false. This paper proceeds with procedures for the heterogeneity and robustness of estimates in the DID models and analysis to ensure that the initial outcomes in the baseline models are robust and stable.

\section{Heterogeneity analysis}

In order to control for the heterogeneity within the sample, this paper runs regressions of the treatment effect of inflation targeting regimes across two sub-groups based on the level of trade openness. In this paper, trade openness is defined as the sum of exports and imports of goods and services measured as a share of GDP. The average percentage of trade openness for sample countries for the study periods from 2002 to 2010 is approximately $60 \%$. Thus, this rate is used to divide countries into two sub-groups. Table 3 represents the outcomes of the heterogeneity test. Similar to previous tables, only the results of the main interests are provided. As per this table, the inflation targeting implementation has a negative and significant impact on the inflation rate during the crisis period in both sub-groups, while the impacts of this policy on output growth are not apparent as the economy copes with the exogenous shock. These results suggest that there is no heterogeneity treatment effect across the groups of trade openness levels. Thus, the estimated treatment effect of inflation targeting in initial results is stable across the sub-groups.

\begin{tabular}{|c|c|c|c|c|}
\hline \multirow[b]{3}{*}{$\begin{array}{l}\text { Independent } \\
\text { variables }\end{array}$} & \multicolumn{4}{|c|}{ Dependent variables } \\
\hline & \multicolumn{2}{|c|}{ Inflation rate } & \multicolumn{2}{|c|}{ Output growth } \\
\hline & $\begin{array}{c}\text { Countries with } \\
\text { trade openness (\% } \\
\text { GDP) less than } \\
60 \%\end{array}$ & $\begin{array}{c}\text { Countries with } \\
\text { trade openness }(\% \\
\text { GDP) greater than } \\
60 \%\end{array}$ & $\begin{array}{l}\text { Countries with } \\
\text { trade openness (\% } \\
\text { GDP) less than } \\
60 \%\end{array}$ & $\begin{array}{c}\text { Countries with } \\
\text { trade openness (\% } \\
\text { GDP) greater than } \\
60 \%\end{array}$ \\
\hline $\begin{array}{l}\text { IT implementation } \\
\text { in the crisis period }\end{array}$ & $-2.271 * *(1.073)$ & $-2.753^{*}(1.616)$ & $-0.089(0.909)$ & $-0.701(1.056)$ \\
\hline IT implementation & $-4.133(4.302)$ & $1.716(5.054)$ & $-0.135(1.803)$ & $-0.848(1.876)$ \\
\hline Number of groups & 31 & 41 & 31 & 41 \\
\hline $\begin{array}{l}\text { Number of } \\
\text { observations }\end{array}$ & 200 & 267 & 200 & 272 \\
\hline$R^{2}$ (within) & 0.215 & 0.168 & 0.260 & 0.374 \\
\hline
\end{tabular}

Note(s): All regressions include constant, covariate variables as specified in the text, fixed time effects, and fixed country effects. Robust standard errors are in parentheses which are clustered at the country level. ** and * indicate statistical significance at the 5 and $10 \%$ level, respectively

Source(s): Author's calculation

Inflation
targeting and
economic
performance

347 


\section{AJEB 6,3}

348

\section{Robustness check}

The Granger-type causality test in Section 5 suggests that estimates for the treatment variable do not change significantly as these leads are included in the model; thus, the initial outcomes in the baseline models are robust. In this section, the paper considers the year 2008 rather than 2007-2009 as the crisis period to further check the robustness of the estimated treatment effect. The dependent variable is now the changes in inflation and output growth between the crisis period 2008 and years before and after this event for the period 2002-2010. Table 4 reports the outcomes of this estimation. As observed in the table, the estimated coefficients associated with the IT dummy variables are not significantly different in comparison to the initial results. The estimated treatment effects of the inflation targeting on inflation rate are still insignificant in comparison to the pre- and post-policy adoptions during stable periods. However, inflation targeting works well in controlling the inflation rate during economic turmoil periods in IT countries relative to non-IT countries. When the output growth acts as the dependent variable, there is no significant difference between IT and nonIT countries in terms of the performance of this indicator during different periods covering the crisis. This outcome confirms that driven findings in this paper are robust.

\section{Summary and conclusions}

The increasing popularity of inflation targeting as a monetary framework over the last three decades partially suggests the effectiveness of this policy; however, the empirical evidence on its impact on economic performance shares limited consensus. This paper contributes to the existing research by conducting a comprehensive analysis of the treatment effect of inflation targeting two macro indicators, namely inflation rate and output growth, over the period of the global financial crisis which was considered a great recession starting in 2007. In doing so, the effectiveness of this popular monetary framework in mitigating consequences from such exogenous economic uncertainties is carefully examined.

The preferable methodological approach in this line of research - the DID model-is employed in this paper. The endogeneity of the IT regimes stemming from time-invariant factors is controlled in a fixed-effect model for the period 2002 to 2010. The sample countries consist of 54 emerging economies with 15 IT countries. When examining the case of emerging countries, the empirical results from this study indicate that inflation targeting reduces the inflation rate during the crisis period, even though the impact of this policy on the inflation indicator is insignificant during the stable periods. In terms of output growth, the inflation targeting regime does not make significant changes within the IT countries, as well as between the IT and non-IT countries over the periods covering the crisis period. This finding has proved to be robust and stable over sub-groups.

\begin{tabular}{|c|c|c|c|c|}
\hline \multirow[b]{3}{*}{ Independent variables } & \multicolumn{4}{|c|}{ Dependent variables } \\
\hline & \multicolumn{2}{|c|}{ Inflation rate } & \multicolumn{2}{|c|}{ Output growth } \\
\hline & Coefficient & Robust SE & Coefficient & Robust SE \\
\hline IT implementation in the crisis period & $-3.248^{* *}$ & 1.252 & 0.595 & 0.781 \\
\hline IT implementation & -3.451 & 3.769 & -0.925 & 0.983 \\
\hline Number of groups & \multicolumn{2}{|c|}{54} & \multirow{2}{*}{\multicolumn{2}{|c|}{54}} \\
\hline Number of observations & \multicolumn{2}{|c|}{467} & & \\
\hline$R^{2}$ (within) & \multicolumn{2}{|c|}{0.131} & \multicolumn{2}{|c|}{0.305} \\
\hline
\end{tabular}

Note(s): All regressions include constant, covariate variables as specified in the text, fixed time effects, and Table 4. fixed country effects. Robust SE is standard error clustered at the country level. ** indicates statistical significance at the $5 \%$ level the crisis period in 2008 Source(s): Author's calculation 
The evidence of this study does not conclude that inflation targeting is the best monetary framework and all countries must adopt it. The outcomes indicate that inflation targeting matters and works well in controlling the inflation rate when emerging countries face an exogenous shock as the global financial crisis in 2007 without significant trade-off performance of output growth. Thus, countries can consider this policy when aiming to stabilize prices during a such crisis.

This study can be extended by examining the impact of inflation targeting on other macro factors of economic performance, such as volatility of inflation rate and output growth, unemployment rate or industrial production performance. While doing this, emerging countries should have a more general view of the effectiveness of this monetary framework on the economy.

\section{References}

Armand, A. (2012), Coping with the Recent Financial Crisis, Did Inflation Targeting Making Any Difference?, University of Orléans, Rue de Blois.

Ball, M. and Sheridan, N. (2004), Does Inflation Targeting Matter?, National Bureau of Economic Research, University of Chicago Press, Chicago, pp. 249-282, doi: 10.7208/chicago/ 9780226044736.003.0007.

Batini, N. and Laxton, D. (2007), "Under what conditions can inflation targeting be adopted? The experience of emerging markets", in Miskin, F. and Schmidt-Hebbel, K. (Eds), Monetary Policy under Inflation Targeting, Central Bank of Chile, pp. 1-38.

Bernanke, S. and Miskin, S. (1997), "Inflation targeting: a new framework for monetary policy?", Journal of Economic Perspective, Vol. 11 No. 2, pp. 97-116, doi: 10.1257/jep.11.2.97.

Bjørnland, H.C. (2004), "The role of the exchange rate as a shock absorber in a small open economy", Open Economies Review, Vol. 15 No. 1, pp. 23-43, doi: 10.1023/B:OPEN.0000009423.30895.fe.

Blinder, S., Ehrmann, M., Fratzscher, M., De Hann, J. and Jansen, D. (2008), "Central bank communication and monetary policy: a survey of theory and evidence", Working Paper No.13932, NBER. doi: 10.3386/w13932.

Claessens, S., Aruccia, G., Igan, D. and Laeven, L. (2010), "Cross-country experiences and policy implications from the global financial crisis", Economic Policy, Vol. 25 No. 62, pp. 267-293, doi: 10.1111/j.1468-0327.2010.00244.x.

de Carvalho Filho, I. (2010), "Inflation targeting and the crisis: an empirical assessment", Working Paper, No.10/45, IMF, pp. 1-22. doi: 10.5089/9781451963045.001.

Edwards, S. and Yeyati, L. (2005), "Flexible exchange rates as shock absorbers", European Economic Review, Vol. 49 No. 8, pp. 2079-2105, doi: 10.1016/j.euroecorev.2004.07.002.

FTSE Russell (2020), "Equity country classification”, FTSE, available at: https://www.ftserussell.com/ equity-country-classification (accessed 12 October 2020).

Gemayel, R., Jahan, S. and Peter, A. (2011), "What can low-income countries expect from adopting inflation targeting?”, Working Paper WP/11/276, IMF. doi: 10.5089/9781463925932.001.

Gonçalves, S. and Salles, M. (2006), "Inflation targeting in emerging economies: what do the data say?", Journal of Development Economics, Vol. 85 Nos 1-2, pp. 312-318, doi: 10.1016/j.jdeveco.2006.07.002.

International Monetary Fund (2005, 2008), (2010), World Economic Outlook, International Monetary Fund, Washington, Distict of Columbia.

International Monetary Fund (2019), Annual Report on Exchange Arrangements and Exchange Restrictions (AREAER), International Monetary Fund, Washington, District of Columbia.

Khandker, R., Koolwal, B. and Samad, A. (2010), Handbook on Impact Evaluation: Quantitative Methods and Practices, The World Bank, Washington, District of Columbia. doi: 10.1596/978-08213-8028-4.

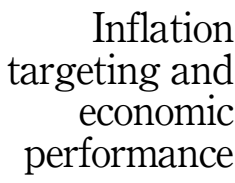


AJEB 6,3

Lin, S. and Ye, H. (2007), "Does inflation targeting really make a difference? Evaluating the treatment effect of inflation targeting in seven industrial countries", Journal of Monetary Economics, Vol. 54 No. 8, pp. 2521-2533, doi: 10.1016/j.jmoneco.2007.06.017.

Lin, S. and Ye, H. (2009), "Does inflation targeting make a difference in developing countries?", Journal of Development Economics, Vol. 89 No. 1, pp. 118-123, doi: 10.1016/j.jdeveco.2008.04.006.

Lucotte, Y. (2012), "Adoption of inflation targeting and tax revenue performance in emerging market economies: an empirical investigation”, Economic Systems, Vol. 36 No. 4, pp. 609-628, doi: 10. 1016/j.ecosys.2012.01.001.

Miskin, S. and Schimidt-Hebbel, K. (2007), "Does inflation targeting make a difference?”, Working Paper No.12876, NBER. doi: 10.3386/w12876.

Neumann, M. and Von Hagen, J. (2002), "Does inflation targeting matter?”, Working Paper, B 01-2002, ZEI. doi: 10.20955/r.84.127-148.

Roger, S. (2010), "Inflation targeting turns 20", Finance and Development, Vol. 47 No. 1, pp. 46-49.

Rose, A. (2007), "A stable international monetary system emerges: inflation targeting is Bretton woods, reserved", Journal of International Money and Finance, Vol. 26 No. 5, pp. 663-681, doi: 10. 1016/j.jimonfin.2007.04.004.

Samarina, A., Terpstra, M. and De Hann, J. (2014), "Inflation targeting and inflation performance: a comparative analysis", Applied Economics, Vol. 46 No. 1, pp. 41-56, doi: 10.1080/00036846. 2013.829205.

Schaechter, A., Stone, R. and Zelmer, M. (2000), Adopting Inflation Targeting: Practical Issues for Emerging Market Countries, International Monetary Fund, Publication Services, Washington, District of Columbia.

Stiglitz, J.E. (2008), The Failure of Inflation Targeting, Project Syndicate, available at: https://www. project-syndicate.org/commentary/the-failure-of-inflation-targeting.

Svensson, L.E.O. (1997), "Inflation targeting in an open economy: strict or flexible inflation targeting", Reserve Bank of New Zealand Discussion Paper Series G97/8, Reserve Bank of New Zealand.

Tapsoba, R. (2010), "Does inflation targeting improve fiscal discipline? An empirical investigation”, Working Papers 201020, CERDI.

Vega, M. and Winkelried, D. (2005), "Inflation targeting and inflation behavior: a successful story?", International Journal of Central Banking, Vol. 1 No. 3, pp. 153-175.

Wing, C., Simon, K. and Bello-Gomez, A. (2018), "Designing difference in difference studies: best practices for public health policy research", Annual Review of Public Health, Vol. 39, pp. 453-469, doi: 10.1146/annurev-publhealth-040617-013507.

\section{Further reading}

Central Bank News (2020), Inflation Target, CentralBankNews.info. available at: http://www. centralbanknews.info/p/inflation-targets.html (accessed 12 October 2020).

Nagy, L. (2016), "From independent Slovakian Central Bank policy to the monetary policy of the euro area”, Focus: New Central Bank Policies, Public Finance Quarterly 2016/1, pp. 49-64.

Nell, M. (2004), "Monetary policy in the Slovak Republic. Implicit inflation targeting and the choice of an optimal exchange rate regime", BIATEC, Vol. 12 No. 11, pp. 1-23.

Williard, L. (2012), "Does inflation targeting matter? A reassessment", Applied Economics, Vol. 44 No. 17, pp. 2231-2244, doi: 10.1080/00036846.2011.564136.

\section{Corresponding author}

Thuy Hang Duong can be contacted at: hang90.duong@gmail.com 
Appendix

Inflation

targeting and economic

\begin{tabular}{lcrrrrr}
\hline Variables & Number of observations & Mean & Standard deviation & Minimum & Maximum & performance \\
\hline Inflation rate & 1,405 & 57.178 & 449.657 & -72.730 & 11749.640 & 18.066 \\
GDP growth & 1,443 & 2.072 & 4.671 & -37.002 & $\mathbf{3}$ & $\mathbf{3 5 1}$ \\
Fixed exchange rate regime & 1,508 & 0.563 & 0.496 & 0.000 & 180.874 \\
M2 growth (\% GDP) & 1,395 & 43.766 & 27.937 & 4.894 & 220.407 \\
Trade openness (\% GDP) & 1,400 & 63.336 & 32.962 & 9.136 & Table A1. \\
Public debt (\% GDP) & 1,384 & 59.499 & 43.281 & 1.030 & 454.860 & Summary statistics \\
& & & & & &
\end{tabular}

\begin{tabular}{|c|c|c|c|c|}
\hline Country & Inflation targeting adoption year & Inflation rate at the adoption date & 2020 inflation target (percent) & \\
\hline \multicolumn{5}{|c|}{ Emerging market countries } \\
\hline Czech Republic & 1997 & 6.8 & $2.0( \pm 1.0)$ & \\
\hline Chile & 1999 & 3.2 & $3.0( \pm 1.0)$ & \\
\hline Colombia & 1999 & 9.3 & $3.0( \pm 1.0)$ & \\
\hline Brazil & 1999 & 3.3 & $4.0( \pm 1.5)$ & \\
\hline South Africa & 2000 & 2.6 & $3.0-6.0$ & \\
\hline Thailand & 2000 & 0.8 & $1.0-3.0$ & \\
\hline Mexico & 2001 & 9.0 & $3.0( \pm 1.0)$ & \\
\hline Hungary & 2001 & 10.8 & $3.0( \pm 1.0)$ & \\
\hline Iceland & 2001 & 4.1 & 2.5 & \\
\hline Philippines & 2002 & 4.5 & $3.0( \pm 1.0)$ & \\
\hline Peru & 2002 & -0.1 & $2.0( \pm 1.0)$ & \\
\hline Guatemala & 2005 & 9.2 & $4.0( \pm 1.0)$ & \\
\hline Romania & 2005 & 9.3 & $2.5( \pm 1.0)$ & \\
\hline Indonesia & 2005 & 7.4 & $3.0( \pm 1.0)$ & \\
\hline Turkey & 2006 & 7.7 & $5.0( \pm 2.0)$ & \\
\hline Armenia & 2006 & 2.9 & $4.0( \pm 1.5)$ & \\
\hline Serbia & 2006 & 10.8 & $3.0( \pm 1.5)$ & \\
\hline Ghana & 2007 & 10.5 & $8.0( \pm 2.0)$ & \\
\hline Uruguay & 2007 & 8.1 & $3.0-7.0$ & \\
\hline Georgia & 2009 & 1.7 & 3.0 & \\
\hline Albania & 2009 & 2.2 & $3.0( \pm 1.0)$ & \\
\hline Paraguay & 2011 & 8.3 & $4.0( \pm 2.0)$ & \\
\hline Uganda & 2011 & 15.1 & $5.0( \pm 2.0)$ & \\
\hline Dominican Republic & 2012 & 3.7 & $4.0( \pm 1.0)$ & \\
\hline Maldova & 2013 & 4.6 & $5.0( \pm 1.5)$ & \\
\hline Russia & 2015 & 15.5 & 4.0 & \\
\hline India & 2015 & 5.9 & $4.0( \pm 2.0)$ & \\
\hline Kazakhstan & 2015 & 6.7 & $4.0-6.0$ & \\
\hline Ukraine & 2016 & 13.9 & $5.0( \pm 1.0)$ & \\
\hline Jamaica & 2017 & 4.4 & $4.0-6.0$ & \\
\hline Costa Rica & 2018 & 2.2 & $3.0( \pm 1.0)$ & \\
\hline \multicolumn{5}{|l|}{ Developed countries } \\
\hline New Zealand & 1990 & 3.3 & $2.0( \pm 1.0)$ & \\
\hline Canada & 1991 & 6.9 & $2.0( \pm 1.0)$ & \\
\hline United Kingdom & 1992 & 4.0 & 2.0 & \\
\hline Sweden & 1993 & 1.8 & 2.0 & \\
\hline Australia & 1993 & 2.0 & $2.0-3.0$ & \\
\hline Israel & 1997 & 8.1 & $1.0-3.0$ & \\
\hline Poland & 1998 & 10.6 & $2.5( \pm 1.0)$ & \\
\hline South Korea & 2001 & 2.9 & 2.0 & \\
\hline Norway & 2001 & 3.6 & 2.0 & \\
\hline Japan & 2013 & 0.3 & 2.0 & Table A2. \\
\hline \multicolumn{4}{|c|}{$\begin{array}{l}\text { Note(s): Countries are classified as inflation targeting countries based on the IMF's Annual Report on Exchange Arrangements and } \\
\text { Exchange Restrictions (AREAER) database } \\
\text { Emerging markets and developed countries are classified based on FTSE country classification of Equity markets in } 2020 \\
\text { Source(s): Roger (2010), IMF (2019), central banks' data }\end{array}$} & $\begin{array}{r}\text { Emerging market and } \\
\text { industrial countries } \\
\text { that have adopted } \\
\text { inflation targeting }\end{array}$ \\
\hline
\end{tabular}


AJEB

6,3

352

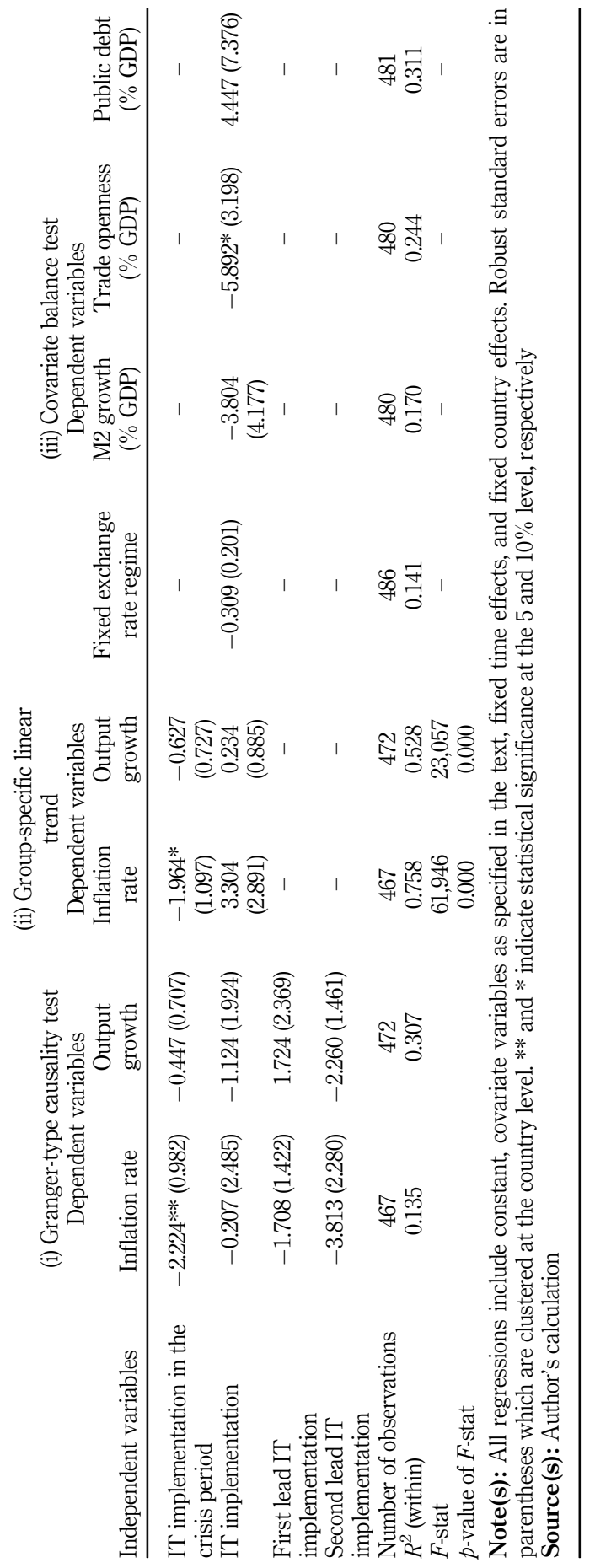

Table A3.

The impact of inflation targeting on the inflation rate and GDP growth from 2002 to 2010, the parallel trend tests 